\title{
The Rule of Law Framework in the European Union: Its Rationale, Origins, Role and International Ramifications
}

\author{
Artur Nowak-Far
}

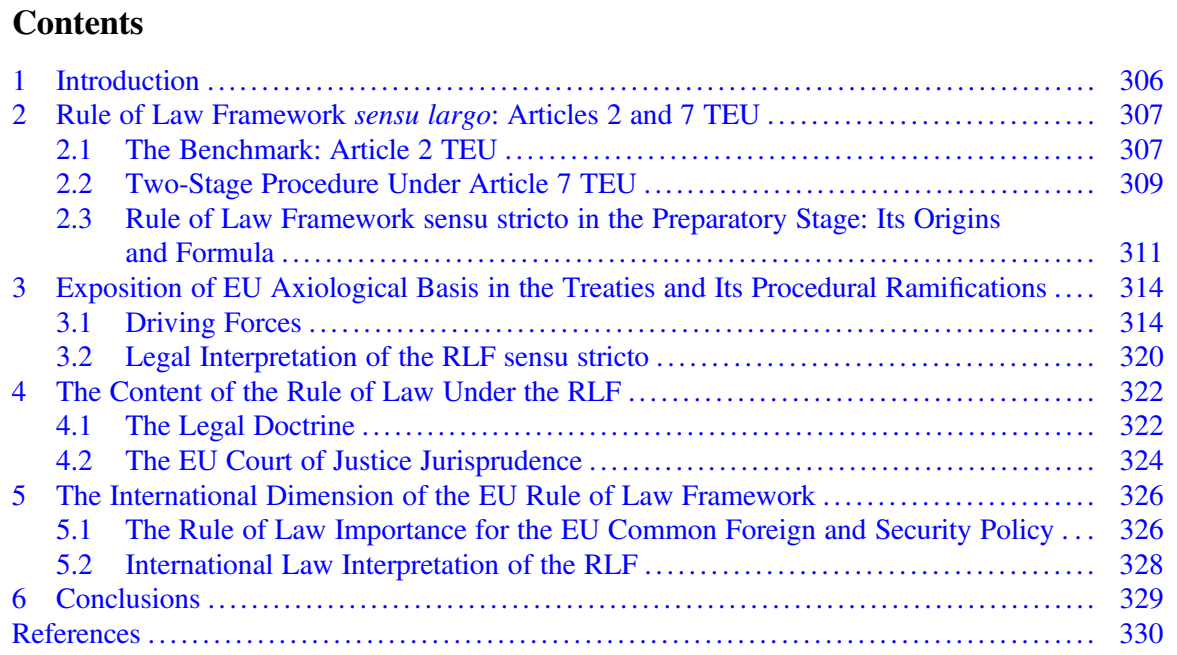

\begin{abstract}
At present, the European rule of law enforcement framework under Article 7 TEU (RLF) is vulnerable to unguaranteed, discretionary influences of the Member States. This vulnerability arises from its procedural format which requires high thresholds in decision-making with the effect that this procedure is prone to be terminated by the EU Member States likely to be scrutinized under it, if only they collude. Yet, the Framework may prove effective to correct serious breaches against human rights (in the context of ineffective rule of law standards). The European Commission is bound to pursue the RLF effectiveness for the sake of achieving relative uniformity of application of EU law (at large), and making the European Union a credible actor and co-creator of international legal order. The RLF is an
\end{abstract}

\footnotetext{
A. Nowak-Far $(\square)$

Institute of Law, SGH-Warsaw School of Economics, Warsaw, Poland

e-mail: artur.nowak-far@sgh.waw.pl
} 
important tool for the maintenance of relative stability of human rights and the rule of law in the EU despite natural divergence propensity resulting from the procedural autonomy of the EU Member States. By achieving this stability, the EU achieves significant political weight in international dialogue concerning human rights and the rule of law and preserves a high level of its global credibility in this context. Thus, RLF increases the EU's effectiveness in promoting the European model of their identification and enforcement.

\section{Introduction}

The Rule of Law Framework (here referred to as 'RLF' or 'the Framework') is a contingency procedure adopted to reflect on these processes of political (and legal constitutional) developments in the European Union Member States which give rise to significant enough doubts of whether these developments are in line with the fundamental standards set forth in the EU Treaties, i.e. the Treaty on the European Union (TEU) and the Treaty on the functioning of the European Union (TFEU). In the context of the RLF, the most important provisions of these two legal instruments are those which specify the constitutional standard values of the European Union as an international organisation and those which provide for a legal basis of the RLF.

For the sake of analysis, two distinctive forms of RLF are distinguished:

(a) RLF sensu largo-which should be construed under Articles 2 and 7 TEU and which includes all other legal vehicles adopted to enforce these two provisions;

(b) RLF sensu stricto-which, for analytical purposes, can be considered the mechanism of enforcement of Article 7 TEU designed by the European Commission and adopted pursuant to its communication of 19 March 2014 (further referred to as 'the RLF communication'). ${ }^{1}$

The objective of this Chapter is to verify the following hypotheses:

1. In the RLF, the political element dominates over the legal one as much of the Framework is owned by the EU Member States rather than by an independent judiciary; in consequence, the very rationale of the RLF is contradictory: at the material level, it is to protect the rule of law where the role of independent judiciary is enshrined, whereas at the procedural level, its fundamental mechanisms rely upon the political will of the EU Member States to protect them; this makes the RLF a relatively easy prey for at least two European Union Member States prone to collude in the situation where, at the same time, they may find themselves within remit of the Framework because of their defiance of the EU Treaty values.

\footnotetext{
${ }^{1}$ Communication from the Commission to the European Parliament and the Council: A New EU Framework to Strengthen the Rule of Law, 10 March 2014, document COM (2014) 158 final/2.
} 
2. Despite this vulnerability, the RLF has significant systemic value as it is able to put on a check all EU Member States' practices which manifestly contravene the values enshrined in the Treaties, including the rule of law; moreover, the RLF is not a final format and is very likely to be further developed into a more stringent, and legally certain construct - which is the area where the European Commission evidently sees its significant role in the future, and where it nurtures its powers vis-à-vis other EU institutions and the Member States.

3. The Commission is bound to pursue its active and, in terms of competences, rather expansionary policy in order to ensure uniformity of EU law enforcement internally and to preserve a high level of EU credibility as a globally significant promotor of human rights.

\section{Rule of Law Framework sensu largo: Articles 2 and 7 TEU}

\subsection{The Benchmark: Article 2 TEU}

The RLF is meant to assure enforcement of EU values enshrined in Article 2 TEU. Article 2 provides that:

The Union is founded on the values of respect for human dignity, freedom, democracy, equality, the rule of law and respect for human rights, including the rights of persons belonging to minorities. These values are common to the Member States in a society in which pluralism, non-discrimination, tolerance, justice, solidarity and quality between women and men prevail.

The provision was adopted originally in the Treaty of Amsterdam in 1997. It was intended to provide for the axiological foundations of the European Union. In the post-Lisbon setting (i.e. after 2008) this provision was meant to create-together with the Charter of Fundamental Rights (which in the Treaty of Lisbon was given binding force) and other, already existing, provisions of EU law (pertaining especially to EU citizenship) — a set of overarching systemic reference for any other EU law provision, if only it concerned rights of individuals.

Article 2 TEU has its direct equivalent in Article I-2 of the Treaty establishing the Constitution for Europe, i.e. the EU treaty of 2004 which had been intended to replace the then present EU Treaty framework but had failed as a result of lack of ratifications in all the EU Member States.

In the EUCJ's jurisprudence of recent years, the question of the interpretation of Article 2 TEU has been deliberated quite frequently especially in the context of mutual trust of judicial systems. Thus, in its opinion $2 / 13^{2}$ (EU accession to the

\footnotetext{
${ }^{2}$ CJEU, Opinion 2/13 of 18 December 2014, Accession of the European Union to the European Convention for the Protection of Human Rights and Fundamental Freedoms, ECLI:EU: C:2014:2454.
} 
European Convention of Human Rights), the Court suggested that this mutual trust required that fundamental to the EU legal system values would be recognized in each and every EU member states as a precondition to the proper implementation of EU law; ${ }^{3}$ this requirement was construed as a straightforward product of the very fabric of EU law which represents 'a structured network of principles, rules and mutually independent legal relations linking the EU and its Member States' ${ }^{4}$ In the judgment of 27 February 2018 in case C-64/16 Associaçao Sindicos dos Juízes Portugueses $(A S J P),{ }^{5}$ the Court held that Article 2 was a pivotal provision for the mutual trust of national judiciaries in the EU jurisdictional system construed pursuant to Article 19 (1) TEU to consist also of national courts. ${ }^{6}$ Thus, guarantees of judicial independence are required also at the national level. ${ }^{7}$ The Court also upheld that the interpretation of art. 19(1) TEU could be rendered independently of whether, in a given situation, Article 51(1) CFR applies. ${ }^{8}$ The issue has also been quite extensively discussed in a series of illustrious opinions presented by Advocate General Evgeni Tanchev. ${ }^{9}$ AG Tanchev adopted a broader, systemic view of respective elements of judiciary reform in Poland (such as, especially, setting forth a lowered cap on the retirement age of judges during their tenure or subjecting the access to judicial positions or advancement in it to a scheme de facto controlled by the executive). In his opinions, he assessed them as contributing to an extensive systemic overhaul of the judiciary defying the relevant EU standards enshrined in the EU Treaty, thus undermining mutual trust principle. All these recent developments has proved to be a departure from a narrower analytical concept which had been adopted by the EU Court of Justice in the case C-286/12 Commission v. Hungary,${ }^{10}$ where the question of judiciary-concerned regulation on judges' age of retirement had been assessed in terms of its compliance with the EU principle of proportionality.

No doubt, the systemic position of Article 2 TEU and the exact content of values it enshrines has also been extensively debated in rule of law-concerned publications. Many of them considered ASJP judgment to have 'conceptional' importance for the whole rule of law discourse in the context of modifications of judiciary systems in some EU member states. ${ }^{11}$ It has been argued in literature that the existing

\footnotetext{
${ }^{3}$ Id., para. 168 .

${ }^{4}$ Id., para. 167.

${ }^{5}$ ECLI:EU:C:2018:117.

${ }^{6}$ Id., para. 30 .

${ }^{7}$ Id., para. 42.

${ }^{8}$ Id., para. 29

${ }^{9}$ Opinions in cases C-619/18 Independence of the Polish Supreme Court of 11 April 2018, ECLI: EU:C:2019:325; C-192/18 (retirement age of judges) of 20 June 2019, ECLI:EU:C:2019:529; C-585/18, C-524/28, C-625/18 Polish National Judiciary Council, Disciplinary Chamber of the Supreme Court of 27 June 2019, ECLI:EU:C:2019:551.

${ }^{10}$ Judgment of 6 November 2012, ECLI:EUI:C:2012:687.

${ }^{11}$ Pech and Platon (2018), pp. 1827-1854; Krajewski (2018), pp. 395-405; Bonelli and Claes (2018), pp. 622-643.
} 
infringement procedures proved to be badly needed to defend basic principles of EU law and that they are paramount for the development of the underlying legal concept. ${ }^{12}$ Some authors argued that the rule of law procedures were important to maintain the EU axiological system intact despite possible or existing stresses arising from the ever-changing political strains in the EU member states. ${ }^{13}$ The TEU arrangements for the protection of rule of law were interpreted as unique as they were meant to provide for cooperation and axiological consensus instrumental for the EU to maintain its character as a polity of constitutional quality able to effectively protect its citizens whenever whey happen to enjoy EU law rights. ${ }^{14}$

Systemic approach and adequate institutional arrangements were considered to be of acute importance for the effectiveness of the existing EU rules meant to promote and/or protect EU values. ${ }^{15}$ It has been argued that a causal model of infringement of values enshrined in Article 2 TEU was needed to make liability of the Member State possible under art. 7 TEU. ${ }^{16}$

\subsection{Two-Stage Procedure Under Article 7 TEU}

A rough equivalent of Article 7 appeared in the EU legal system in 1997, with the successful ratification of the Treaty of Amsterdam. Now it is one of the provisions of the Treaty of Lisbon. Article 7 can be applied in two distinctive situations emerging in the EU Member States:

(a) in a situation of a 'clear risk of a serious breach (...) of the values referred to in Article 2';

(b) in a situation of a 'serious and persistent breach (...) of the values referred to in Article 2'.

These two situations are addressed upon in two distinctive provisions of Article 7: its paragraph 1 and 2, respectively. Depending on specific circumstances, these provisions can be applied one after another, or-if the gravity of the situation commends it - just paragraph 2 can apply even from the very outset. In the former case, the two paragraphs concerned represent a two-stage description of the situation in which the breach of the values referred to in Article 2 has persisted over sufficiently long time or even aggravated.

For each of the so distinguished stages, different modes of situation identification and application of corrective measures apply. In each of these models a fairly

\footnotetext{
${ }^{12}$ Prete (2017), pp. 6-10, 301-304.

${ }^{13}$ Kochenov (2017), pp. 9-27.

${ }^{14}$ Tichý (2018), pp. 85-108.

${ }^{15}$ Itzcovich (2017), pp. 28-43; Schmidt and Bogdanowicz (2017), pp. 1069-1073.

${ }^{16}$ Bagińska and Majkowska-Szulc (2018), pp. 125-144.
} 
complex and subtle interplay of the European Commission, the European Parliament, the Council, the European Council and the Member States is granted.

The procedure of Article 7(1) is initiated by $1 / 3$ of the EU Member States, or the European Parliament of the European Commission; under Article 7(2) the mode of the initiation is the same, with the exception that the European Parliament cannot trigger the procedure. The core institution making the pivotal decision for each procedure is different for paragraph 1 and 2. In Article 7(1) procedure, the decision is made by the Council (in its General Council formation, i.e. in the format made up of the European affairs ministers from all EU Member States) acting with a very challenging $4 / 5$ majority of votes. In contrast, in Article 7(2) procedure, the decision on the existence of 'a serious and persistent breach (...) of values referred to in Article 2' is to be made by the European Council. Only within the procedure under Article 7(1), the Council may address to the Member State (under the preliminary RLF scrutiny) its corrective recommendations prior to the determination that this Member State experiences a situation of 'a clear risk of a serious breach of the values referred to in Article 2'. The European Council is not empowered to take a similar step under Article 7(2).

The procedures of Article 7(1) and Article 7(2) can be distinguished also by their different outcomes. Under Article 7(1), the Council is invested with the right to regularly verify whether the grounds on which the Member State considered was determined to experience 'a clear risk of a serious breach (...) of values referred to in Article 2'. In contrast, in the aggravated situation falling within the ambit of Article 7 (2), the outcome of the procedure is that the Council would now be empowered (pursuant to Article 7(3)) to decide (by a qualified majority) 'to suspend certain of the rights deriving from the application of the Treaties to the Member States in question'. This coercive suspension may take the form of excluding the Member State's representative from voting in the Council; the suspension can as well involve any negative deformation of the regular rights of the Member State under the TEU and TFEU. The only limitations applicable to the power of the Council in this context is that-under Article 7(3) TEU-it should 'take into account the possible consequence of such a suspension on the rights and obligations of natural and legal persons'. Because of a high position of general principles of law in the EU legal system, the Council should also make its measures applied under Article 7(3) in line with these principles, especially with the principle of proportionality. Yet, as any overview of the Court of Justice jurisprudence may indicate, only serious, 'manifest' errors in this principle application are most likely to make the measures so adopted subject to annulment by the Court of Justice. ${ }^{17}$ Moreover, these measures may escape any EU Court of Justice's scrutiny initiated by natural and legal persons, as under the well-established Plaumann doctrine they are required to substantiate that the contested measures are uniquely applicable to the person challenging themwhich is a difficult task. In other words, the decisions adopted under Article 7(3) are

\footnotetext{
${ }^{17}$ See the judgment in the case 25-62 Plaumann \& Co. v. Commission, ECR [1963] 95. See also: Arnull (2006), pp. 41-49.
} 
bound to be quite enduring in the EU legal system. ${ }^{18}$ The RLF Treaty procedures specified in Article 7 is graphically depicted in Fig. 1.

The Treaty does not offer any further or more detailed elaboration of the system of Article 7 enforcement. This implies that neither does it give any guidelines which may apply to the systematic monitoring of the situation in respective Member States prior to the application of Article 7. This shortage is quite striking when the system of Article 7 TEU is compared with the EU system of enforcement of rules of economic governance set forth in Articles 121 and 126 TFEU as the latter system is elaborated in a significant number of secondary legal acts which set forth detailed rules on the evaluation of relevant criteria and procedural aspects of their application.

The Treaty model of RLF, as it is, is quite vulnerable to the Member States' collective will to trigger its respective stages even in a rather hypothetical situation of serious infringements of any of them against the values enshrined in Article 2 TEU. This vulnerability arises from the very demanding unanimity threshold for the decision made under Article 7(2), i.e. the one which would determine 'serious and persistent breach of the values referred to in Article 2' by one of the EU Member States. It is therefore enough that two EU countries will simultaneously be subject to the RLF procedure to make it manifestly ineffective as each of these countries would be able to vote on the case of another. Such a voting 'complot' is not a novelty in the EU: e.g. exactly this type of cooperative behavior prevented the Council from making its decision effective in the seemingly much less vulnerable system of economic governance. ${ }^{19}$

\subsection{Rule of Law Framework sensu stricto in the Preparatory Stage: Its Origins and Formula}

European Union statutory law does not contain any specific provisions concerning the evaluation of the situation in any Member States with regard to Article 7 TEU. In other words, the initiation criteria for the RLF or the procedure applicable to the initiation of Article 7 application have not been detailed in the Treaties or any legislative legal acts. The fact that the EU law falls short of expectations with regard to the enforcement mechanisms of Article 7 (in connection with Article 2) TEU has not gone unnoticed to many actors of the EU legal system. The most pronounced political initiative to improve this situation was undertaken by a group of Northern EU Member States: Denmark, Finland, Germany, and the Netherlands which advocated for the development of an instrument which would make it possible to monitor the internal rule of law in EU Member States on a permanent basis. In the programming document of this initiative, a 2013 report titled 'Respect and Justice for All',

\footnotetext{
${ }^{18}$ Tridimas (2000), pp. 89-123.

${ }^{19}$ See the judgment in the case C-27/04 Commission v. Council, ECR [2004] I-6649. See also e.g. Andersen (2012), p. 27.
} 


\section{Stage 1 (Article 7(1) TEU)}

Proposal made by either:

(a) $1 / 3$ of EU member States

(b) the European Parliament

(c) the European Commission

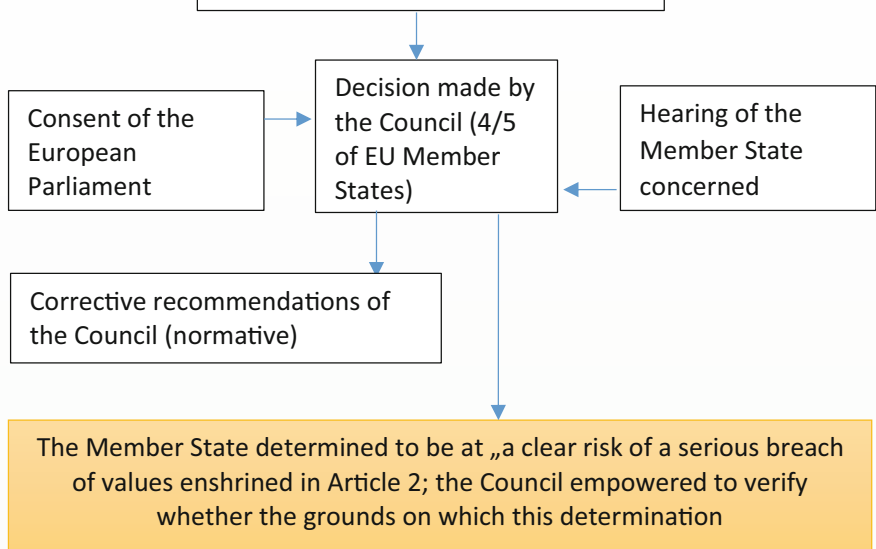

Stage 2 (Article 7(2) TEU)

Proposal of:

(a) $1 / 3$ of Member States

(b) the Commission

Submission of observations by the Member

State concerned

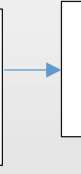

Unanimous decision
of the European
Council

Consent from the European

Parliament

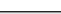

The Member State determined to have a situation of the existence of a 'serious and persistent breach of the values referred to in Article 2'

Coercive decisions of the Council (made by a qualified majority): 'suspension of rights deriving from the Treaties'

Fig. 1 Procedure of Article 7 paragraphs 1-2 TEU (Treaty of Lisbon). Source: Artur Nowak-Far 
the Dutch Ministry of Foreign Affairs explained the rationale of the initiative in the following way:

...the rule of law does not always function sufficiently well, even within EU member states. To strengthen the rule of law within Europe, the government seeks to promote transparent governance, independent judiciaries, respect for human rights, antidiscrimination policy and legislation to curb corruption and conflicts of interest (...) Countries wanting to join the EU must comply with strict accession criteria in the realm of the rule of law and human rights (the Copenhagen criteria $\left.{ }^{20}\right)(\ldots)$ At the moment, there are still too few resources to call member states to account after their accession to the EU. Ideally, there should be a mechanism within the EU enabling member states to remind each other of their obligations on the basis of equality. There is already a system of this kind in the framework of the United Nations, but the EU also has a responsibility to tackle problems in its own house on a political level. ${ }^{21}$

The initiative coincided with some actions undertaken in the EU institutions: In June 2013 the Justice and Home Affairs Council and the European Parliament, respectively. The former called on the Commission 'to take forward the debate in line with the Treaties on the possible need for and shape of a collaborative and systematic method' to monitor the observance of EU values in respective EU Member States and address detected departures from the generally accepted standards. $^{22}$ The European Parliament requested that 'Member States be regularly assessed on their continued compliance with the fundamental values of the Union and the requirement of democracy and the rule of law. ${ }^{23}$

The said RLF initiative did not earn any firm enough support from other Member States which remained neither neutral or negative to it. The Hungarian government already feared that the procedure would be used against it; some governments (like the Polish one, at least for some time) perceived it as an 'elitist' procedure which would be used by the 'better' states (most likely the 'old' EU members) to scrutinize political practices of the 'worse' countries (most likely to be the 'new' EU Member States, i.e. the ones which acceded past 2004 and which, indeed, had to meet the Copenhagen criteria). Some other Member States perceived the RLF as a tool to expand the European Commission's realm of authority-something they were reluctant to easily accept.

Regardless of these hurdles, in response to these initiatives, the European Commission came up with its own communication concerning the procedure which could be used for activating the mechanisms foreseen in Article 7 TEU. ${ }^{24}$ According to the Commission's own statement, the proposed rules were to 'precede and complement

\footnotetext{
${ }^{20}$ For the explanation of this point refer to the next section of this chapter.

${ }^{21}$ Ministry of Foreign Affairs of the Netherlands (2013), p. 20.

${ }^{22}$ Press release 3244th Council Meeting - Justice and Home Affairs, Luxembourg 6-7 June 2013, document 10461/13 (OR.en).

${ }^{23}$ European Parliament, Committee on Civil Liberties, Justice and Home Affairs, Report of 17 February 2014 on evaluation of justice in relations to criminal justice and the rule of law, rapporteur Kinga Göncz, document A7-0122/2014.

${ }^{24}$ See supra Fig. 1.
} 
Article 7 TEU mechanisms'; their application was to be 'without prejudice to the Commission's powers to address specific situations falling within the scope of EU law by means of infringement procedures under Article 258 TFEU' (i.e. its powers to start up an EU law infringement procedure before the European Union Court of Justice). Where there are clear indications of a systemic threat to the rule of law in a Member State, the Commission can launch a 'pre-Article 7 Procedure' by initiating a dialogue with that Member State through the Rule of Law Framework.

According to the Commission communication, the RLF procedure has three stages:

(a) the assessment stage-where the Commission collects and examines all the relevant information and assesses whether there are clear indications of a systemic threat to the rule of law; at this stage, if the Commission's concerns have been substantiated, it would initiate a dialogue with the Member State concerned by sending its 'Rule of Law Opinion' to that state;

(b) the recommendation stage-where the Commission would address its 'Rule of Law Recommendation' to the Member State concerned, in which this EU institution would make public expected actions and their applicable time-framework - all meant to improve the situation in the Member State concerned,

(c) the follow-up stage-where the Commission would monitor the Member State's action and, if it found the State's performance unsatisfactory, it would trigger Article 7 procedure - either on its own, or by prompting $1 / 3$ of the Member States or the European Parliament to do so.

The RLF (sensu stricto) can thus be interpreted also as a system of structured discourse as it involves a continuous dialogue and exchange or views between the Commission and the Member State concerned and between the European Parliament and the Member States (represented within the Council).

\section{Exposition of EU Axiological Basis in the Treaties and Its Procedural Ramifications}

\subsection{Driving Forces}

The idea to expose the EU axiological basis in a EU treaty has been on the agenda for a long time prior to the entry into force of the Treaty of Lisbon (in December 2009). The sense of urgency with regard to this exposition emerged as a result of the following two phenomena:

(a) the EU enlargement negotiations which started in 1998 and were successfully concluded in 2004 and resulted in accepting a group of Central and Eastern European countries as new Member States of the EU,

(b) the emergence of the authoritarian right-wing coalition in Austria (in the period of 2000-2002). 
One of the challenges of the EU enlargement negotiations which involved a group of Central and Eastern European countries (i.e. Czech Republic, Estonia, Latvia, Lithuania, Hungary, Poland, Slovakia, Slovenia) was their authoritarian heritage (in fact, a little bit less extensive for the Czech Republic, as prior to WWII, it had been a fully-feathered liberal democracy). All these 8 countries had a Communist past, the Baltic States (i.e. Estonia, Latvia, and Lithuania) were even the component republic of the USSR until 1991. For this reason, the rule of law and other EU democratic values were included in the EU membership criteria negotiation package, most importantly in the form of the so called 'Copenhagen Criteria'. These were set forth by the European Council in its summit Conclusions of June 21-22 1993. The most relevant requirement was formulated in the following way:

Membership requires that the candidate country has achieved stability of institutions guaranteeing democracy, the rule of law, human rights and respect for and protection of minorities, the existence of a functioning market economy as well as the capacity to cope with competitive pressure and market forces within the Union. Membership presupposes the candidate's ability to take on the obligations of membership including adherence to the aims of political, economic and monetary union. ${ }^{25}$

Thus, throughout the negotiations, the incumbent States were required to modify their institutional and legal systems in a way which could guarantee that the Copenhagen Criteria were met. Interestingly, the question of meeting the Copenhagen Criteria had not been an issue in the $1995 \mathrm{EU}$ enlargement which included Austria, Finland, and Sweden, but had again been quite important in the $2007 \mathrm{EU}$ enlargement onto Bulgaria and Rumania and in 2013 when they were again applied to Croatia. The problem with the sheer application of the Copenhagen Criteria was, however, that - from the perspective of the EU legal order-these criteria represent non-binding set of rules (which does not mean that they cannot be considered to form contractual obligations-reference under international law). This means that they could effectively be applied whenever, in the context of EU membership negotiations, there was enough conditionality to enforce adequate standards in the EU membership-aspiring countries; yet this element was lost whenever they entered the EU as the European Council's presidency conclusions of 1993 were not even their own original political commitment but rather something imposed 'from outside'. Thus, in order to avoid departures from the negotiated standards, an adequate amendment of the Treaty appeared to be badly needed.

As it has already been said, the other phenomenon which prompted the process of adoption of adequate Treaty standards of democracy, the rule of law, human rights, and the protection of minorities was that of the political rise of right, authoritarian parties in Austria. The phenomenon found its pivotal moment after the 1999 parliamentary elections in Austria when the radical right party, Freedom Party of Austria (Freiheitliche Partei Österreichs, FPÖ), was able to create a coalition with the mainstream Social Democrats (Sozialdemokratische Partei Österreichs, SPÖ).

\footnotetext{
${ }^{25}$ European Council in Copenhagen. Conclusions of the Presidency, June 21-22, 1993, document SN 180/1/93 REV 1, p. 14.
} 
What now (unfortunately) appears not so unusual anymore, had in 2000 come as a surprise because of a controversial, nationalistic, anti-immigration, and authoritarian penchant of the controversial FPÖ's leader Jörg Haider. The resulting situation made it visible, that the only pressure other EU Member States could exert on the EU country whose policy might not be completely in line with the EU values was the political pressure (in fact, intra-EU cooperation with the Austrian government then was limited), but no firm legal tool could be used.

The first ever legislative reaction to the threat of rightist populists was the amendment of the Treaty introduced by the Treaty of Amsterdam (1997), often referred to as 'Lex Austria'. Namely, in Article F.1, the Treaty was given a new provision which provided that:

The Union is founded on the principles of liberty, democracy, respect for human rights and fundamental freedoms and the rule of law, principles which are common to the Member States.

It is quite striking that, when compared to Article 2 of the present TUE, Article F (1) TUE (the Amsterdam version) made its reference to a narrower catalogue of values. Moreover, it made a reference to liberty which is not made any more in the present Treaty. Its reference to human rights goes together with the reference to fundamental freedoms-whereas the present Treaty does not contain a reference to the latter value. Most importantly, Article F(1) TUE does not contain any specific catalogue of values which pertain to the societies of the Member States (such as pluralism, non-discrimination, tolerance, justice, solidarity, and equality between women and men); rather, it points out an axiological network which should be 'common the Member States' but which apparently 'stem from the fundamental EU legal order'.

In Article F.1., the Amsterdam Treaty set forth, for the first time, a RLF procedure, yet it was quite distinctive from the present one. The most important difference is that the Amsterdam RLF was a single-stage procedure with the pivotal role of the Council, acting in a very special format (not used anymore in the EU institutional order) of the heads of states or governments (i.e. with no participation of the President of the Council nor any of its own President, as this position had never existed for this very special type of the Council). The Council was to act by unanimity on a proposal by $1 / 3$ of the Member States or by the Commission and after obtaining the assent of the European Parliament-which is the same arrangement as the one used now (also with respect to the majority requirements). Article F.1 provided also that the Council's decision should be made only after inviting the Member State concerned to submit its observations. The procedure was to be concluded with the determination by the Council of 'the existence of a serious and persistent breach by a Member State of principles mentioned in Article F(1)'. When such a conclusion had been adopted in the decision, the Council, acting by a qualified majority, might decide to suspend certain of the rights deriving from the application of this Treaty to the Member State in question, including the voting rights of the representative of the government of that Member State in the Council. The Amsterdam RLF procedure is depicted in Fig. 2. 


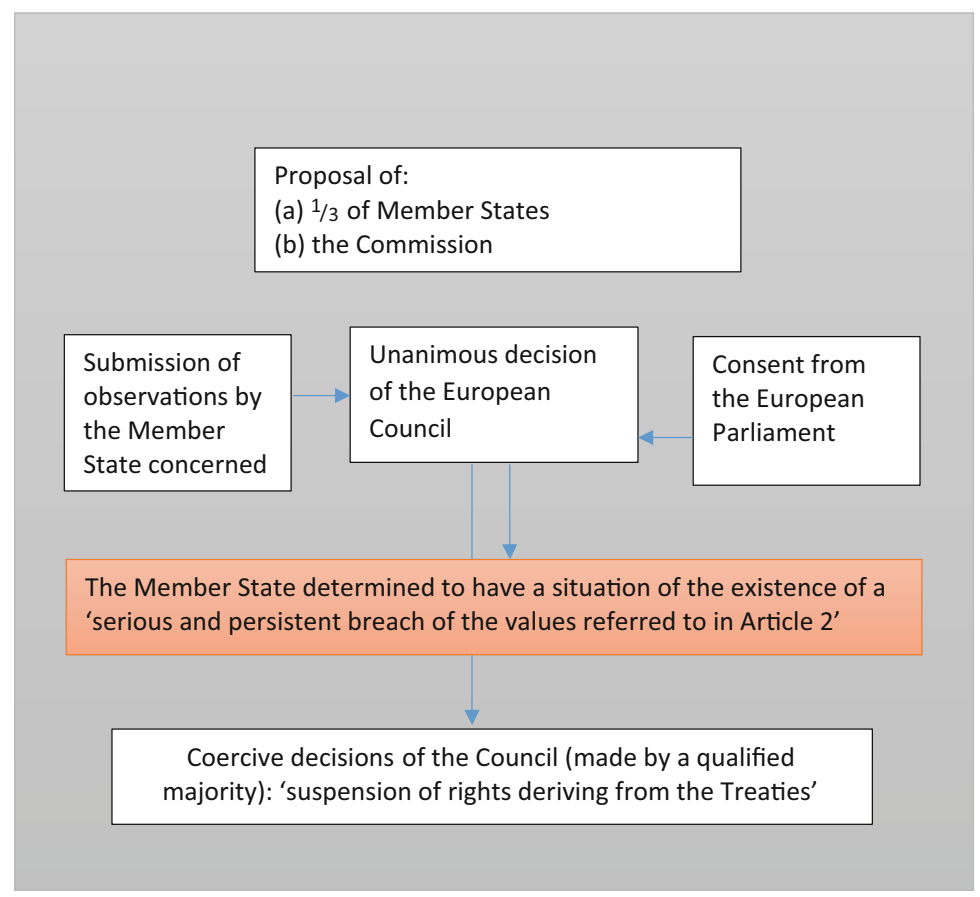

Fig. 2 Single stage RLF procedure of Article 7 TEU (Article F.1. of the Treaty of Amsterdam). Source: Artur Nowak-Far

Article F.1. TEU contained the same modalities as the present Article 7(2). Namely, the Council decision on the suspension of rights of the Member State put under the RLF scrutiny had to take into account 'the possible consequences of such a suspension on the rights and obligations of natural and legal persons'. It could also, acting by a qualified majority, decide to vary or revoke measures originally adopted with respect to that Member States-reflecting on changes in the underlying situation.

The RLF procedure specified in the Amsterdam Treaty was quickly considered too rigid and inflexible as it did not allow for any preliminary stage where the Member State concerned could be involved in a dialogue on its practices. Thus, Article 7 TUE was amended in the subsequent revision of the TEU, now in the Treaty of Nice (2000).

The rule of law became an important element of the agenda within the negotiation of the EU Constitutional Treaty, which, in Article I-2 enshrined it together with other values deemed inextricably interwoven with it: democracy and the human rights. Moreover, it contained a clause not only stating that the EU-specific values listed in it are 'common' to the EU Member States, but also formulating requirements concerning the axiological fabric of their societies-all in the format which was later adopted in the Treaty of Lisbon as well. Thus, the wording of Article I-2 of the Constitutional Treaty was as follows: 
The Union is founded on the values of respect for human dignity, freedom, democracy, equality, the rule of law and respect for human rights, including the rights of persons belonging to minorities. These values are common to the Member States in a society in which pluralism, non-discrimination, tolerance, justice, solidarity and equality between women and men prevail.

With regard to the RLF procedure, the Constitutional Treaty, in Article I-59, took over the wording of the Treaty of Nice. Interestingly and uniquely for the Constitutional Treaty, this act made also reference to these values in its preamble. It also contained numerous clauses which provided significant guidelines for interpretation of the values enshrined in its Article I-2. Interestingly, it also extended the requirements of the rule of law onto EU institutions, as well.

The Constitutional Treaty, adopted in 2004, had been intended to replace the then present EU treaty framework. Yet, it was a failed endeavor-as it had failed to win ratifications in all the EU Member States.

Soon after its failure, the EU Member States began the negotiation of a major revision of the then existing treaties (TEU and the Treaty establishing the European Community, TEC). These negotiations were successful. They produced a new version of the TEU and transformed the TEC into its major revision named the Treaty on functioning of the European Union. The new treaties (technically speaking resulting from the accord called the Treaty of Lisbon), were duly ratified and entered into force in December 2009.

This, however, has not solved the problems of an effective enforcement of the rule of law in the EU. A possibility for the EU venue to achieve a high enough standard in this area would be to accede to the European Convention of Human Rights and Fundamental Freedoms (ECHR). Yet, the EU failed to do it. The EU failure to make an accession to the European Convention of Human Rights and Fundamental Freedoms (ECHR) occurred despite the fact that the Convention is referred to in Article 6 TEU which

(a) in its paragraph 2 provides that the Union shall accede to the ECHR, yet that 'such accession shall not affect the Union's competences as defined in the Treaties',

(b) in its paragraph 3, provides that fundamental rights, as guaranteed by the Convention shall (together with the fundamental rights resulting from constitutional traditions common to the Member States) constitute general principles of the EU law.

The former provision was intended to defy the Court of Justice's negative opinion issued in 1994 (i.e. the opinion 2/94 ${ }^{26}$ ) which upheld that with no express legal Treaty basis, the Community was not entitled to accede to the ECHR. This 'defying' effect seemed to be even reinforced by a modification of the ECHR itself, by the introduction of the Protocol No. 14, which in Article 17 provided for a change in Article 59(2) ECHR with the effect that it now expressly foresaw the EU accession to

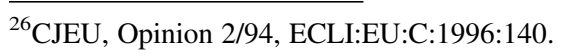


the Convention. The process of accession seemed to be reinforced by the fact that, by virtue of the Lisbon Treaty, the EU Chapter of Fundamental Rights (CFR) had been included into the EU legal system as a binding instrument. ${ }^{27}$ As such, it required that the rights enshrined in it be identical with the rights arising from the ECHR (Article 52(3) CFR), yet with an important reservation that these rights be not interpreted in departure from the established EU law, international public law (at large) and international conventions to which the Union or all its Member States were counterparties (Article 53 CFR).

The specific conditions on which the EU was to accede to the ECHR were set forth in the Protocol No. 8 attached to the Treaty of Lisbon. This Protocol set forth the following principles applicable to the accession:

(a) the principle of inter-semiotic retention (set forth in Article 1), i.e. the requirement that the accession should make it possible to retain specific features of the $\mathrm{EU}$ and the EU legal system (especially with regard to the participation of the EU in controlling mechanisms of the ECHR);

(b) the principle of non-modification of external and internal powers of the EU (Article 2, first sentence),

(c) the principle of non-modification of the status of the EU Member States in the ECHF legal order (Article 3, second sentence);

(d) the principle of exclusive competence of the EU Court of Justice with regard to disputes concerning the interpretation and application of EU Treaties (Article 3 of the Protocol in connection with Article 344 TFEU).

In its opinion $2 / 13,{ }^{28}$ the EU Court of Justice upheld that the already negotiated agreement on the EU accession to the ECHR should not be signed. One of the most significant arguments which prompted the Court to conclude negatively was that the accession to the ECHR would result in a deformation of the principle of mutual trust inherent in the EU legal system. This principle implies that the Member States should not double-check, in any legal action context, whether other Member States observe fundamental rights guaranteed by the Union. ${ }^{29}$ Nevertheless, such rights should be interpreted 'within the framework of the structures and objectives of the Union ${ }^{30}$ which are determined by EU substantive law. In the case of doubt, national courts can refer to the Court of Justice within the preliminary questions procedure

\footnotetext{
${ }^{27}$ The Chapter of Fundamental Rights had been considered to have just a 'declaratory' value before. ${ }^{28} \mathrm{CJEU}$, Opinion 2/13 of 18 December 2014, Accession of the European Union to the European Convention for the Protection of Human Rights and Fundamental Freedoms, ECLI:EU: C:2014:2454.

${ }^{29} \mathrm{Id}$, para. 191 of the Opinion 2/13, supra note 2. See also the CJEU's judgment of 25 June 2018 in the case C-216/18 PPU LM, ECLI:EU:C:2018:586 in which the Court upheld that such a doublechecking should guarantee rights conferred to EU citizens under Article 47 CFR; the CJ emphasized that the check should be based on specific and detailed analysis of the underlying situation and should take into account the specific situation of an individual concerned as well as the information provided for by the Member State whose legal system is to be trusted.

${ }^{30}$ Id, para. 170 .
} 
under Article 267 TFEU. This important legal arrangement cannot be reconciled with the mechanisms of application of ECHR, as - among others-any interpretation offered by the EU Court of Justice could not be binding to the separate Court of Justice operating under the Convention. Instead, judiciary decisions of that latter court would be binding onto the EU Court of Justice which could undermine the principles set forth in Protocol No. 8.

Interestingly, this does not mean that the EU Treaties and the ECHR represent two legal systems immune from each other. In practice, they are in a constant intersemiotic dialogue (i.e. the dialogue in which two separate, yet interlegible 'institutional languages' are employed) as the judgments under the ECHR are often treated as a type of preliminary rulings by the EU Court of Justice. ${ }^{31}$ In turn, the ECHR Court sometimes invokes the EU preliminary questions procedure under Article 267 TFEU considering denial of its application a breach of the ECHR (i.e. its Article 6(2) which prohibits denial of justice). ${ }^{32}$ However, regardless of this dialogue, the linkage between the ECHR and the EU legal order proved to be insufficient to provide for a stronger enforcement mechanism of the EU values, especially those enshrined in the Charter of Fundamental Rights and in Article 2 TEU.

\subsection{Legal Interpretation of the RLF sensu stricto}

The legal meaning of the procedure set forth in Article 7 TEU does not yield any specific concerns as to its legal binding force. In contrast, the RLF sensu stricto does give rise to some concerns about its legal force which would likely be raised by the Member States subject to any form of the European Commission's scrutiny in the context of Article 7.

Admittedly, the RLF sensu stricto was set forth in the European Commission communication (i.e. the RLF communication). The communication is not included in the list of binding legal acts specified in the Treaties; most importantly, it is not covered by Article 288 TFUE, which provides that regulations, directives and decisions have binding force in the EU legal system. Thus, the RLF communication can be considered an act of soft law.

The European Commission was empowered to make the RLF communication as it was meant to 'precede and complement Article 7 TEU mechanisms' and provide transparency in the Commission's own actions-as such a specification can be

\footnotetext{
${ }^{31}$ See e.g. the judgment in the case C-404/15 and C/659/15 Criminal Proceeding against Pál Aranyosi and Robert Căldăraru, ECLI:EU:C:2016:198 (where the Court upheld that the European Arrest Warrant can be denied effect with respect to the Member State being persistently in contravention of the ECtHR - what has already been confirmed in the ECtHR judgments in Vociu v. Rumania, Application No. 22015/10, Bujorean v. Rumania, Application No. 13054/12, Varga et al. v. Hungary, Applications No. 14097/12, 45135/12, 73712/12, 34001/13, 44055/13, 64586/13.

${ }^{32}$ ECtHR Dhahbi v. Italy, Application No. 17120/09.
} 
considered a specification of the Commission's general powers arising from this Treaty provision. The rules set forth in the RLF communication can be interpreted as a measure to eliminate uncertainty of law resulting from the incompleteness of rules specified in Article 7 with regard to the triggering of the mechanism of RLF (sensu largo). Thus, the procedure foreseen in it is meant to produce legal (and at the end of the day, binding) effect, yet the RLF rules (sensu stricto) are deprived of a binding force. In the terminology developed by Susan Senden, the RLF communication can be classified as a decisional communication (as contrasted to informational or interpretative ones), i.e. a communication which provides for general rules regarding the way in which the already existing implementing powers will be exercised, in particular, indicating, how the Commission will apply binding law provisions in respective cases and how it will make use of the applicable discretion at its disposal. ${ }^{33}$ Decisional communications are not binding but are apt to produce legal effects by virtue of some other rules to which they pertain and to which they pragmatically relate. In the specific RLF (sensu stricto) context, the RLF communication derives its legal effectiveness from the fact that it is meant to make sure that the application of Article 7 should commence on a well-reasoned and adequately substantiated basis. As such, the RLF sensu stricto could make the application of Article 7 much more informed than without it. Moreover, as it performs an obvious signaling element, the RLF sensu stricto guarantees that the Member States concerned would not be surprised with the decision to become subject to measures under Article 7. More than that-they will have a chance to get involved in a dialogue with the Commission where they would be able to submit their own argumentation concerning the rule of law situation.

It is a matter of serious doubt whether the Member States subjected to the RLF sensu stricto would be able to challenge the recommendations addressed to them within this procedure before the EU Court of Justice (under Article 263 TFEU, i.e. within the action of annulment of an EU legislative act). The doubt arises from at least two issues:

(a) the formal one, which is based on an argument that Article 263 TFEU overtly excludes annulment actions brought against Commission's recommendations,

(b) the material one, which is based on an argument that, even if Article 263 TFUE were applicable (as-because of the clear intention to produce legal effect- the 'recommendations' under the RLF could be re-interpreted as acts falling within the remit of actions for annulment ${ }^{34}$ ), at the end of the day, they could not be challenged as they do not represent a final measure, but are rather steps in a procedure to be completed and to involve challengeable legal acts. ${ }^{35}$

\footnotetext{
${ }^{33}$ Senden (2004), pp. $148-149$.

${ }^{34}$ See e.g. the EU Court of Justice judgment in the case C-362/08 P Internationaler Hilfsfonds $\mathrm{eV}$ v. Commission, ECLI:EU:C:2010:40, para. 52; 22/70 Commission v. Council, ECLI:EU: C:1971:32, para. 42.

${ }^{35}$ The argument per analogiam based on the EU Court of Justice (the Court of First Instance) judgment in the case T-126/95 Dumez v. Commission, ECLI:EU:T:1995:189.
} 
Not being able to challenge the RLF recommendations, the Member States concerned, if only determined enough, would likely disregard them (as it was recently the case with Poland). Since (genuine) recommendations are not binding legal acts, the Commission will not be able to bring an action against the Member States concerned (under Article 258 TFEU) for not fulfilling them. Yet, this non-fulfillment will be a significant evidence in any further proceedings under Article 7.

This conclusion is in the same time an argument supporting the Commission's competence to issue the RLF recommendations. In the context of the entire RLF, they represent an important element of the dialogue between the Commission and the Member State concerned. The fact that the Member State ignored them (if this is the case) becomes an element of the argumentation sued for triggering the Article 7 procedure against this state.

\section{The Content of the Rule of Law Under the RLF}

To complete the analysis presented in this article, it is quite essential to identify what exactly is meant under the term 'rule of law' in the context of the RLF, regardless of its narrow or broader form. As the term does not have any Treaty definition, it is quite in place to rely on the legal doctrine and the EU Court of Justice's jurisprudence to answer this question.

\subsection{The Legal Doctrine}

More is known about what the rule of law is not than what it exactly is-especially in national contexts. Yet, basic conditions for the rule of law can be identified in the existing body of literature. ${ }^{36}$ It is most often held that the rule of law is achieved whenever the following requirements are met:

(a) law generality - law should be general; particular regulation should be avoided;

(b) law publicity_law should be made public, known to those whom it concerns;

(c) law non-retroactivity-law should not act retroactively;

(d) law cataphaticity - law should be understandable to its primary stakeholders;

(e) law relative stability-law should be kept stable, whenever there are not good reasons to amend it;

(f) systemic consistency-legal norms of the system should be consistent with each other;

(g) law observability - it should be possible for law stakeholders to observe it;

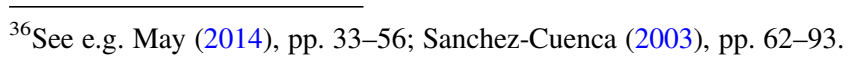


(h) behavioral congruence between legal norms and stakeholders' actions-all stakeholders should effectively observe the law.

Adriaan Bedner divided the features/requirements of the rule of law into three classes:

(a) procedural:

- the presence of the rule by law, i.e. the situation where the state actions are subject to law;

- the law formalization, which requires that it is understandable, stable and predictable);

- the creation of law in democratic procedures, i.e. under conditions requiring that the legislative consent should determine or at least influence legal actions)

(b) substantive:

- the law subordination to justice;

- the protection of individual rights and liberties;

- the respect to human rights and group rights

(c) controlling:

- the independence of judiciary;

- the responsibility of administrative and other independent bodies for reviewing legal process. ${ }^{37}$

Interestingly, most of these requirements are primarily addressed to law-makers. Some of them require a good ex ante foresight into the expected perceptions/ reactions of those who would be most likely and/or most strongly concerned with a given piece of law. It is striking that all of these requirements are formulated in procedural terms or, if they concern the content, they are highly abstract. As a result, the question about the 'content' law under the rule of law is quite justified.

One possible answer to this question is that the rule of law is about providing for conditions in which 'right' relationships between the government and citizens as well as between each and every citizen is set. 'Right' means, that the resulting setting is capable to protect and enforce individual rights and to give framework for a large degree of responsibility and accountability in the government. Some answers aspire even higher, as they would consider the 'real' rule of law to guarantee a perfect impartiality of the law-making system.

\footnotetext{
${ }^{37}$ Bedner (2010), pp. 56-69.
} 


\subsection{The EU Court of Justice Jurisprudence}

The rule of law was highlighted in the European Union relatively often in various forms. Most importantly in 1986, in its enshrined judgment in the case 294/83 Parti écologiste 'Les Verts' v. European Parliament, ${ }^{38}$ the Court of Justice held that the Community was a 'community of law' - and reminded that it required the consistency of all law (including national law) with the Treaty serving as a 'basic constitutional charter' (i.e. the systemic anchor of the entire, so defined, legal system). In 1993, the European Council formulated the so called 'Copenhagen Criteria' applicable to all states aspiring for EU membership, in which conformity with the 'rule of law' was enshrined. In 1997, the Treaty of Amsterdam made referrals to rule of law in Article 6 and the new suspension mechanism of Article 7 (so called Lex Austria). On some occasions, the Court of Justice upheld the idea that the EU was also subject to the rule of law. In its judgment in the case C-50/00 $P$ Unión de Pequeños Agricultores v. Council, ${ }^{39}$ the CJ stated that rule of law required consistency of EU secondary law with fundamental rights (see also similarly in joint cases C-402/05 P and C-415/05 P Yassin Abdullah Kadi and Al Barakaat International Foundation v. Council and Commission ${ }^{40}$ ). As it has already been argued, the most recent CJ's jurisprudence has contributed significantly to this rather rudimentary understanding of the concept of rule of law-most importantly in the realm of judiciary. The most recent development of CJ jurisprudence established a link between Article 2 TEU and Article 19(1) TEU as well as the due process standard set forth in Article 47 CFR (concerning the right to an effective remedy and to a fair trial). The CJ construed the EU legal system as the one which is complete and fully capable to enforce all rights conveyed by the EU law onto EU citizens or undertakings, provided that the Member States effectively ensure judicial protection of these rights. ${ }^{41}$ In such a complete system, the respective judicial systems, at both national and supranational levels, sport mutual trust to each other. ${ }^{42}$ Yet, this trust is subject to the results of a careful double-checking procedure which can be triggered by national courts whenever there are substantiated grounds that the values enshrined in Article 2 TEU are not fully observed or implemented in another Member State. ${ }^{43}$ The issue can be expected to be developed further as many cases concerning the rule of law issue are still pending. So far, they have been extensively discussed in a series

\footnotetext{
${ }^{38}$ ECLI:EU:C:1986:166.

${ }^{39}$ ECLI:EU:C:2002:462.

${ }^{40}$ Judgment of 3 September; ECLI:EU:C:2008:461.

${ }^{41}$ Judgment of 6 March 2018 in the case C-284/16 Slovak Republic v. Achmea BV, ECLI:2018:158; see especially para 36 .

${ }^{42}$ E.g. Opinion 2/13 of 18 December 2014, supra note 2; judgment of 27 February 2018 in case C-64/16 Associaçao Sindical dos Juízes Portugueses (ASJP), ECLI:EU:C:2018:117, para. 39.

${ }^{43}$ Judgment of 5 April 2016 in the case C-404/15 and C-659/15 PP Aranyosi and Câldâraru, ECLI: EU:C:2016:198, para 104; judgment of 25 June 2018 in the case C-216/18 PPU LM, supra note 29 , para 23.
} 
of illustrious opinions presented by Advocate General Evgeni Tanchev, ${ }^{44}$ who adopted a broader, systemic approach in reviewing judiciary system quality in a Member State.

All these actions have contributed to the understanding of the EU concept of the rule of law. Yet, they definitely are not sufficient to make it possible to construe an independent, EU-specific definition of it. The wording of Article 2:

The Union is founded on the values of respect for human dignity, freedom, democracy, equality, the rule of law and respect for human rights, including the rights of persons belonging to minorities... (emphasis added)

suggests that the rule of law is one of the values on which the EU is founded and that it is somehow different from other values enshrined in this particular provision of the Treaty. We also know (from other provisions of the Treaty as well as from the $\mathrm{CJ}$ jurisprudence) that the principle of procedural autonomy applies to the EU Member States. In the procedural realm, its rectifications in CJ's judgments in e.g. cases 21-24/72 International Fruit Company NV et al. v. Produktschap voor Groenten en Fruit,${ }^{45}$ C-188/89 A. Foster et al. v. British Gas plc, ${ }^{46}$ 103/88 Fratelli Costanzo v. Comune di Milano ${ }^{47}$ indicate that its major aspect is the Member States' free hand in shaping their basic constitutional (institutional) order. This means that also the rule of law (as it has been construed under Article 2 TEU) can be applied in divergent procedural settings of now numerous EU Member States. As a result, uniformity of application of 'the rule of law' (and almost all other standards of EU law) in the European Union is far from an ideal pattern attempted by the EU Court of Justice. In consequence, 'uniform EU law' is-by definition-divergent in real settings, where real interests of EU citizens are at stake. In other words, there is a great deal of intersemiotic discourse of EU Member States' judicial and administrative systems over EU law purported to be 'uniform'. Nevertheless, the already discussed recent developments in CJ's jurisprudence clearly indicated that the substantive concept of rule of law heavily relies on the judiciary independence of the executive.

\footnotetext{
${ }^{44}$ Opinions in cases C-619/18 Independence of the Polish Supreme Court of 11 April 2018, ECLI: EU:C:2019:325; C-192/18 (retirement age of judges) of 20 June 2019, ECLI:EU:C:2019:529; C-585/18, C-524/28, C-625/18 Polish National Judiciary Council, Disciplinary Chamber of the Supreme Court of 27 June 2019, ECLI:EU:C:2019:551.

${ }^{45}$ Judgment of 12 December 1972; ECLI:EU:C:1972:115.

${ }^{46}$ Judgment of 12 June 1990: ECLI:EU:C:1990:313.

${ }^{47}$ Judgment of 22 June 1989; ECLI:EU:C:1989:256.
} 


\section{The International Dimension of the EU Rule of Law Framework}

\subsection{The Rule of Law Importance for the EU Common Foreign and Security Policy}

The fact that the initiative for increased enforcement of the rule of law within the Treaty of Lisbon system was promoted by the foreign affairs services of a group of the EU countries is quite telling about the significance of that idea for the EU external policy. It is enough to say that the TEU (in Article 21(1)) requires the EU foreign service (operating within the framework of the EU Common Foreign and Security Policy, $\mathrm{CFSP}^{48}$ ) to consider the rule of law to be one of its guiding principles (together with democracy, the universality and indivisibility of human rights and fundamental freedoms, respect for human dignity, the principles of equality and solidarity and respect for the Principles of the UN Charter and international law). Pursuant to Article 21(2) TEU, the Union shall define and pursue international common policies and actions which, inter alia, consolidate and support democracy, the rule of law, human rights and the principles of international law. As a result, the rule of law has become an idea well pronounced at various levels and in various fora where the EU is represented.

As a matter of fact, in the international sphere, the EU promotes its own model of human rights and-within it - the rule of law. Generally speaking, this model emphasizes the importance of the individual's dignity and individual rights - the ideas deeply rooted in the European Enlightenment. The rule of law can be considered a comprehensive instrument of safeguarding these rights and enforcing them in a uniform manner. Thus, the RLF mechanisms are vital for assuring that-despite the existing procedural divergences in respective EU Member States' legal systems - the EU preserves the integrity of the EU human rights model, and that the EU as an actor of international relations, maintains its high credibility in promoting this model. In other words, the RLF is meant to curb the existing divergence and achieve some uniform standards in the system of enforcement of human rights in order to attract global adherence.

The problem of a proper (i.e. complete and functional) intersemiotic translation of international human rights standards into domestic ones (i.e. the transposition of one legal-pragmatic model of making them reality into another) is pronounced even in systems of common legal tradition and philosophy. With regard to the relationship between legal systems of the Western legal and political tradition, Ernest A. Young noticed, that even when we looked to such systems which, with no doubt, shared common heritage and reflected the same or significantly similar axiological fundaments, we saw 'divergence rather than convergence on many aspects of values and

\footnotetext{
${ }^{48}$ I.e. the subject matter of the provisions of Title V TEU.
} 
political culture' ${ }^{49}$ This not very encouraging conclusion is even more applicable to the relationship between the Western legal and political traditions and its more distant counterparts. The underlying prevalent local social circumstances, moral attitudes and customs may determine a significant gap between the Western concept of human rights and their popular/political acceptance beyond the Western world. This gap may also serve as a political excuse for a national policy of not pursuing any ambitious programme of human rights promotion. Moreover, the recent tensions within the EU which urged the Commission to make recourse to the RLF with respect to Poland were fundamentally caused by the fact that the present Polish government emphasized its different stance to human rights-as it does not seem to share the respect too common to most EU states legal tradition and philosophy stemming strongly from the ideas of the European Enlightenment. Instead, it prefers to derive its legitimacy from rather obscure and unclear ideas of social collectivism and Catholic nationalism.

In order to be effective, international human rights (that is the rights adopted in a context of an international agreement for the purpose of their more or less universal application), must be suitable for their at least relatively equivalent intersemiotic translation-that is their transformation into legal norms expressed in an international statute into legal norms of a given national system. ${ }^{50}$ As a result, international standards will only be 'common' either if the transformation system is apt to act effectively and efficiently and/or if translated common standards represent a low enough denominator (which could be detrimental to the international level of human rights protection). Irrespective of the systemic capacity of intersemiotic translation or structural complexity of norms being translated, a firm and welcoming constitutional approach is required to make human rights enshrined in an international law instrument subject to such a translation. The resulting divergence eliminates 'an axiological common ground' to which respective EU Member States could refer in their EU wide and global discourse on human rights. As a result, this discourse could be deprived of important common reference framework which could have brought these counterparties closer to each other and make legal measures reconciliation more likely to achieve.

It is obvious that this problem is not only bilateral. In the globalized world, bilateral reciprocity shortages become aggregated so that they are increasingly likely to cause acute frictions between legal systems which tend to be more often exposed in the area of consular protection and asylum granting. As a result, they may become a source of a wide dispute over the general roles of the state needed to make the international order an effective and efficient system in which various communities and individuals can achieve levels of welfare not achievable under non-cooperative conditions. In respective areas relevant for the formulation and implementation of national and/or regional public policies, such a lack of reciprocity and the resulting inter-systemic friction would reduce effectiveness of these policies, thus reducing an

\footnotetext{
${ }^{49}$ Young (2005), pp. 161-166 (referring to the Thompson judgment, 487, US 830).

${ }^{50}$ See, e.g. Tiefenbrun (2010), pp. 263-280.
} 
aggregate level of total global welfare which-under more concurrence and cooperation-might have reached higher levels.

\subsection{International Law Interpretation of the RLF}

In legal terms, the modern European human rights concept (including its procedural frameworks such as RLF) represents a departure from a 'traditional bottom line' standard defining inter-relational aspects of international law set forth in the 1927 PCIJ Lotus judgment ${ }^{51}$ holding that international law (and thus, the human rightsrelevant international law) is essentially about relations among states. Today, international law, and especially human rights and the rule of law component of it is a law about global governance which is a concept extending well beyond the relationships amongst states. Global governance can be defined as 'the sum of many ways individuals and institutions, public and private, manage their common affairs'. The practice follows this approach putting in the radar of both international law and human rights (being its significant element) not only states but also non-state actors (especially individuals and their more or less formalized groupings). It does so through the application of international law norms conceived not only as a result of state consent but also of general pressure resulting from a broad consent of all legitimate international law and human rights stakeholders to pursue basic common values of humankind. In modern times such a pressure has become a driving force for shaping international normative agenda. ${ }^{53}$

Having said that, it is important to emphasize that states still play the most important role as international law operators and human rights guarantors (through their own substantive and procedural guarantees producing the rule of law). Thus, at the end of the day, their consent to any conceived norms in these realms still plays the dominant role in legitimating a broad enough and effective (judiciable) recourse to those values in an international scale (in state-setting). To some extent, this pronounced role of states represents an argument usually somehow less pronounced but worth mentioning that only effective assets of international relations really count in international law and human rights promotion.

The essential problem of today's international relations, international law and thus human rights defined in broad terms (i.e. also as a source of potential inspiration for a global governance practice) is at what level of aggregation of their respective standards should be conceived and, consequently, how universally, they can or should be applied and enforced. In such a context, the EU effort to maintain some uniformity in its human rights and the rule of law context can be interpreted as an

\footnotetext{
${ }^{51}$ [1927] PCIJ 10 Series A, 18.

${ }^{52}$ Commission on Global Governance (1995), Our Global Neighbourhood: The Report of the Commission on Global Governance.

${ }^{53}$ See discussion presented in: Thirlway (2014), pp. 8-16.
} 
effort to achieve significant 'weight' able to attract other, non-EU states to follow the European pattern or at least to become an important reference point for the international discussion on the nature, scope of application and the mode of enforcement of human rights.

\section{Conclusions}

1. The Rule of Law Framework (sensu largo) is vulnerable to unguaranteed, discretionary influences of the Member States. This vulnerability arises from its procedural format which requires high thresholds in decision making-with unanimity applicable to the decision which could make it possible for the EU institutions to effectively address any situation in a EU Member States where the rule of law standards have been considered unsatisfactory. With such a mode of the applicable decision-making, RLF procedures are prone to be terminated as a result of collusions made by EU Member States likely to be scrutinized, if at least two of them wish to cooperate with each other in order to abort the RLF procedure brought against one of them.

2. Yet, any serious breaches of an EU Member State of human rights (in the context of ineffective rule of law standards) could single it out within the Union. As a result, in breaches of significant gravity, such a state would not be able to attract cooperation needed for the collusive termination of the RLF. Thus the Framework can have some positive impact on respective EU Member States' behaviour with regard to their respect to human rights.

3. This effect is even reinforced by an active stance of the European Commission which is bound to pursue the RLF effectiveness for the sake of achieving relative uniformity of application of EU law (at large), and making the European Union a credible actor and co-creator of international legal order. The Commission is determined to play an active role also because this allows it to make an important statement on its own institutional powers vis-à-vis other EU institutions and the EU Member States.

4. The RLF is an important tool for the maintenance of relative stability of human rights and the rule of law in the EU despite natural divergence propensity resulting from the procedural autonomy of the EU Member States. By achieving this stability, the EU achieves significant political weight in international dialogue concerning human right and the rule of law and preserves a high level of its global credibility in this context. Thus, RLF increases the EU's effectiveness in promoting the European model of their identification and enforcement.

5. It is rather difficult to judge about the universal acceptability of the European evolving concept of human rights. Admittedly, they may be considered attractive because of the universality of their underlying axiology and their comprehensiveness as a legal concept reflexing the Western idea of broadly understood individual and collective welfare. Such general elements can be considered sufficient to serve as a low enough denominator which is widely acceptable to 
serve as an element of the 'international order' and to enforce other elements of it. Moreover, high standards of protection of a vast catalogue of human rights in the Western world have contributed to the effectiveness and efficacy of its political and economic systems. They have done so by reinforcing largely adequate mechanisms of public choice generally based on the determination of prevailing preferences via political elections, protection of minority groups, and on the well-functioning system of balance of powers. As soon as the prevailing preferences are unveiled, they have to be translated into respective public policies formulated and implemented at various stages of the organization of polity. This has an important bearing on the content of public policies: in their goals, objectives and instruments which—under such a system—take a proper account of human rights.

\section{References}

Andersen S (2012) Enforcement of European Union law: the role of the European Commission. Oxford University Press, Oxford

Arnull A (2006) The European Union and its Court of Justice. Oxford University Press, Oxford

Bagińska E, Majkowska-Szulc S (2018) Causation as a requirement for the Member State liability under Art. 7 TEU in conjunction with Art. 2 TEU. In: Hatje A, Tichý L (eds) Liability of Member States for the violation of the fundamental values of the EU. Nomos, Baden-Baden, pp $125-144$

Bedner A (2010) An elementary approach to the rule of law. Hague J Rule Law 2(1):48-74

Bonelli M, Claes MN (2018) Judicial serendipity: how Portuguese judges came to rescue the Polish judiciary. Eur Const Law Rev 14(3):622-643

Commission on Global Governance (1995) Our global neighbourhood: the report of the commission on global governance. Oxford University Press, Oxford

European Council in Copenhagen. Conclusions of the Presidency, June 21-22, 1993, document SN 180/1/93 REV 1

European Parliament, Committee on Civil Liberties, Justice and Home Affairs, Report of 17 February 2014 on evaluation of justice in relations to criminal justice and the rule of law, rapporteur Kinga Göncz, document A7-0122/2014

Itzcovich $G$ (2017) On the legal enforcement of values: the importance of the institutional concept. In: Jakab A, Kochenov D (eds) The enforcement of EU law and values: ensuring Member States' compliance. Oxford University Press, Oxford, pp 28-43

Kochenov D (2017) The Acquis and its principles: the enforcement of the 'law' vs. the enforcement of 'values' in the European Union. In: Jakab A, Kochenov D (eds) The enforcement of EU law and values: ensuring Member States' compliance. Oxford University Press, Oxford, pp 9-27

Krajewski M (2018) Associaçao Sindicos dos Juízes Portugueses: the Court of Justice and Athena's dilemma. Eur Pap 3(1):395-405

May C (2014) The rule of law: the common sense of global politics. Edward Elgar, Cheltenham

Ministry of Foreign Affairs of the Netherlands (2013) Human Rights Policy - Respect and Justice for All. The Hague

Pech L, Platon S (2018) Judicial independence under threat: the Court of Justice to the rescue in the ASJP case. CLMR 55(6):1827-1854

Press release 3244th Council Meeting - Justice and Home Affairs, Luxembourg 6-7 June 2013, document 10461/13 (OR.en)

Prete L (2017) Infringement proceedings in EU law. Kluwer Law Int 6-10:301-304 
Sanchez-Cuenca I (2003) Power, rules, and compliance. In: Maravall JM, Przeworski A (eds) Democracy and the rule of law. Oxford University Press, Oxford

Schmidt M, Bogdanowicz P (2017) The infringement procedure in the rule of law crisis. In: Closa C, Kochenov D (eds) Reinforcing rule of law oversight in the European Union. OUP, Oxford, pp 1069-1073

Senden S (2004) Soft law in European Community law. Hart Publishing, Oxford

Thirlway H (2014) The sources of international law. Oxford University Press, Oxford

Tichý L (2018) The nature and requirements for liability of a Member State under Article 7. In: Hatje A, Tichý L (eds) Liability of Member States for the violation of the fundamental values of the EU. Nomos, Baden-Baden

Tiefenbrun S (2010) Decoding international law: semiotics and the humanities. Oxford University Press, Oxford

Tridimas T (2000) The general principles of EC law. Oxford University Press, Oxford

Young EA (2005) Foreign law and the denominator problem. Harv Law Rev 119(148):148-167

Artur Nowak-Far is senior researcher and director of the Institute of Law, SGH-Warsaw School of Economics.

Open Access This chapter is licensed under the terms of the Creative Commons Attribution 4.0 International License (http://creativecommons.org/licenses/by/4.0/), which permits use, sharing, adaptation, distribution and reproduction in any medium or format, as long as you give appropriate credit to the original author(s) and the source, provide a link to the Creative Commons license and indicate if changes were made.

The images or other third party material in this chapter are included in the chapter's Creative Commons license, unless indicated otherwise in a credit line to the material. If material is not included in the chapter's Creative Commons license and your intended use is not permitted by statutory regulation or exceeds the permitted use, you will need to obtain permission directly from the copyright holder. 